University of Nebraska - Lincoln

DigitalCommons@University of Nebraska - Lincoln

Bureau of Sociological Research - Faculty

Publications

Bureau of Sociological Research (BOSR)

2-1-2006

\title{
Infertility: Testing a Helpseeking Model
}

Lynn K. White

University of Nebraska - Lincoln, Iwhite3@unl.edu

Julia McQuillan

University of Nebraska - Lincoln, jmcquillan2@Unl.edu

Arthur L. Greil

Alfred University, Alfred, New York, NY

David R. Johnson

Penn State University, drjlks@yahoo.com

Follow this and additional works at: https://digitalcommons.unl.edu/bosrfacpub

Part of the Sociology Commons

White, Lynn K.; McQuillan, Julia; Greil, Arthur L.; and Johnson, David R., "Infertility: Testing a Helpseeking Model" (2006). Bureau of Sociological Research - Faculty Publications. 8.

https://digitalcommons.unl.edu/bosrfacpub/8

This Article is brought to you for free and open access by the Bureau of Sociological Research (BOSR) at DigitalCommons@University of Nebraska - Lincoln. It has been accepted for inclusion in Bureau of Sociological Research - Faculty Publications by an authorized administrator of DigitalCommons@University of Nebraska - Lincoln. 
Published in Social Science E Medicine 62:4 (February 2006), pp. 1031-1041;

doi:10.1016/j.socscimed.2005.11.012 http://www.sciencedirect.com/science/journal/02779536

Copyright (C) 2005 Elsevier Ltd. Used by permission.

Published online December 19, 2005.

\title{
Infertility: Testing a Helpseeking Model
}

\author{
Lynn White, ${ }^{\mathrm{a}}$ Julia McQuillan, ${ }^{\mathrm{a}}$ Arthur L. Greil, ${ }^{\mathrm{b}}$ and David R. Johnson ${ }^{\mathrm{c}}$ \\ a Department of Sociology, University of Nebraska-Lincoln, Lincoln, NE 68588-0324, USA \\ ${ }^{\mathrm{b}}$ Division of Social Sciences, Alfred University, Alfred, New York, NY 14802, USA \\ ' Department of Sociology, Penn State University, University Park, PA 16802, USA
}

Corresponding author: Lynn White, tel 402 472-6005, fax 402 472-6070, email lwhite3@unlnotes.unl.edu

\begin{abstract}
This paper uses data from a study of 196 infertile women from the Midwestern US to examine a general theory of helpseeking behavior applied to infertility. All of these women report meeting the medical definition of infertility -12 months or more of regular intercourse without conception - at some point in their lives. Only 35 percent of this sample of infertile women identified themselves as having had fertility problems and only 40 percent had sought medical treatment.

Drawing on prior theories of helpseeking, we examine the effects of symptom salience, life course cues, attitudes, predisposing factors, and enabling conditions on helpseeking. We posit a model in which a cognitive dimension (perceived infertility) mediates between these predictors and medical helpseeking. Symptom salience (experienced infertility while actively trying to get pregnant), low parity, and poor subjective health are significantly related to perceived infertility, which is, in turn, significantly associated with helpseeking for infertility. Supporting the conclusion that the cognitive dimension of identifying oneself as infertile is critical to helpseeking, the relationship of symptom salience to helpseeking is partially mediated by perceived problems. Internal health locus of control is associated with lower odds of helpseeking but not to perceived infertility.
\end{abstract}

Keywords: infertility, helpseeking, USA

\section{Introduction}

Ethnographic studies describe infertile women as highly distressed by their situation and as willing to go to extreme lengths to achieve a pregnancy (Greil, 1991). In the US, however, fewer than half of women with current fertility impairments have sought medical help (Chandra \& Stephen, 1998). This paper uses a general theory of helpseeking to examine helpseeking for infertility among a sample of 196 Midwestern US women ages 25-50 who have experienced infertility at some point in their lives.
Because most previous studies of helpseeking for infertility have used clinic samples, they cannot provide data from those who do not seek help and thus offer little insight into the processes that deter helpseeking. The strength of this analysis is the use of a random sample of women who meet a medical definition of infertility, one used in medical settings failure to conceive after 12 months of unprotected intercourse-independent of helpseeking. Among this sample, only $40 \%$ reported medical helpseeking. Drawing on general theories of helpseeking, we examine two processes hypothesized to occur sequen- 
tially: cognitive appraisal (perception of a fertility problem) and medical helpseeking.

\section{Background}

\section{Theories of helpseeking}

Across a wide array of physical conditions, from cancer to heart disease, patterns of helpseeking have important effects on treatment outcomes. As a result, a substantial body of theory has developed to explain who seeks help and when. From the beginning, it has been assumed that cognition plays an important role in treatment seeking. Anderson's (1968) Behavior Model of Health Services Utilization postulates that medical helpseeking is a function of perceived and evaluated need, predisposing factors (such as age, gender, past health, socio-economic status, and health beliefs), and enabling factors (such as income, medical care availability, community resources). More recently, Pescosolido (1992) emphasized the need to consider the social contexts in which health decisions are made and the dynamic nature of treatmentseeking trajectories. These various theoretical threads have been summarized succinctly in Shaw's (1999) framework for studying illness behavior.

Empirical work using this model generally has assumed that the central problem is why people who recognize symptoms of illness do not seek help. In a well-known ethnographic study, however, Zola (1973) suggests that recognition of symptoms is not automatic. Symptoms are ubiquitous, and the likelihood that a given symptom will be interpreted as a sign of illness depends on perceived interference with personal and social relationships and sanctions from significant others. In his seminal work on illness behavior, Mechanic (1968) argued that symptoms will be more salient when they disrupt activities of daily life.

Because infertility is signaled, not by the development of new symptoms, but by the continuation of regular menses, perceiving failure to conceive as a symptom of infertility is particularly problematic. Drawing from Mechanic and Zola, we assume that interpreting this continuity as a signal of infertility depends on the degree to which it disrupts personal plans, i.e., on the degree to which one had planned to have a child.

Once fertility is perceived as a problem, the individual may progress to consideration of solutions, including medical treatment. Although perception of a problem is hypothesized to be a critical determinant of getting treatment, theory suggests that medical treatment seeking is also affected directly by two kinds of factors - predisposing and enabling conditions. Predisposing conditions, such as education, health locus of control, general health, and attitudes toward treatment, make individuals likely to consult physicians across a variety of kinds of symptoms. Such consultations may produce diagnoses and treatment recommendations in the absence of patientidentified symptoms. Enabling conditions, such as income, health insurance, and location make it possible for people to get care they desire. In addition, theory suggests that medical treatment seeking should be affected by social networks and by the same individual and social circumstances that encourage one to recognize the symptoms of infertility. We hypothesize that these factors will affect behavioral responses directly but may also be modified by cognitive responses. For example, the positive effects of higher income and social support on helpseeking may be more pronounced among those who perceive they have an infertility problem than among those who do not.

\section{Prior research}

Socio-demographic studies reveal wide variation among societies in the proportion of infertile women who have sought treatment, ranging from less than half in the US, which lacks a comprehensive national health care system, to $67 \%$ in Finland, $86 \%$ in the Netherlands, and 72-95\% in the UK (van Balen, Verdurmen, \& Ketting, 1997). In the US, treatment is expensive and often not covered fully by health insurance plans. As a result, income and health insurance are strong predictors of treatment seeking (Chandra \& Stephen, 1998). Across a wide range of national systems, women with primary infertility (i.e., infertility prior to a first birth) are more likely to seek help than women with secondary infertility (Schmidt \& Münster, 1995).

Most studies of infertility treatment are based on samples of treatment seekers and thus focus on consequences of treatment rather than predictors of helpseeking (c.f., Malin, Hemminki, Raikkonen, Sihvo, \& Perala, 2001). An exception is research by van Balen et al. (1997), who examined the motivations of infertile Dutch women who considered various options for dealing with infertility, including medical treatment, adoption, foster care, alternative medicine, and 
changed life goals. Van Balen and Verdurmen (1999) reported that low-medical anxiety and longer duration of infertility were significant predictors of choosing treatment among Dutch women.

Several studies of treatment discontinuation also shed light on factors that deter treatment. Social support (Fortier, Wright, \& Sabourin, 1992) and optimism about treatment outcomes (Callan, Kloske, Kashima, \& Hennessey, 1988; Malcolm \& Cumming, 2004) have been found to be more important than demographic characteristics, commitment to having a child, or actual likelihood of treatment success. Thus, these studies affirm the importance of social psychological processes in treatment seeking.

Although not focusing on infertility, studies of treatment seeking for other conditions provide empirical evidence regarding theoretically important predictors (Shaw, 2001). This literature suggests that co-morbidity, general use of healthcare, salience of symptoms, deviance of symptoms, and interference with daily life predict helpseeking for conditions as diverse as psychological problems (Lefebvre, Lesage, Cyr, Toupin, \& Fournier, 1998), pre-menstrual syndrome (Robinson \& Swindle, 2000), urinary incontinence (Hannestad, Rortveit, \& Hunskaar, 2002), and brain tumors (Salander, Bergenheim, Hamberg, \& Henrikkson, 1999). Finally, as theory suggests, social network support (Carpentier \& White, 2002) and especially spousal support (Salander et al., 1999) are related to helpseeking. Research on response to hypothetical cancer symptoms suggests that the respondent's belief in the efficacy of medical treatment also encourages help seeking (de Nooijer, Lechner, \& de Vries, 2003; Hunter, Grunfeld, \& Ramirez, 2003).

\section{Statement of the problem}

Drawing from a larger sample of 580 Midwestern women interviewed in 2002, we identified 196 women who had ever had an experience with infertility, as defined in the medical context, i.e., failed to conceive within 12 months of sexual intercourse without contraception (Sciarra, 1994). This 12-month criterion has been established by physicians within a medical setting to identify women who are trying to conceive and might benefit from intervention; it is independent of clinical findings such as low ovarian function and rests wholly on the absence of conception. This definition is widely used in epidemiological studies of both the industrialized and non-industrial- ized world and is independent of whether the couple was actually intending to conceive (Chandra \& Stephen, 1998; Schmidt \& Münster, 1995). Our approach includes the entire reproductive career of a cross-section of women ages 25-50. The lifetime approach enlarges the pool of women who have experienced infertility, including women who had children despite low fertility as well as the childless, and provides a long time frame for helpseeking and cognitive processing of symptoms.

We examine a two-step model (see Figure 1) in which symptom salience, life course variables, individual and social cues, and predisposing and enabling factors are hypothesized to affect perception of infertility and, directly and indirectly, medical helpseeking. We further test whether the effect of these variables on helpseeking depends on perceiving a problem.

Prior work suggests that an important predictor of perception should be symptom salience, conceptualized as the degree to which the symptoms interfere with personal plans (Mechanic, 1968; Zola, 1973). Indicators of infertility salience include whether the woman was actively trying to get pregnant (rather than merely at risk of pregnancy) during this period of unprotected intercourse and the strength of her intention to bear future children.

We hypothesize that life course cues are important triggers for appraising lack of conception as a fertility problem and for seeking help. In this data set, these

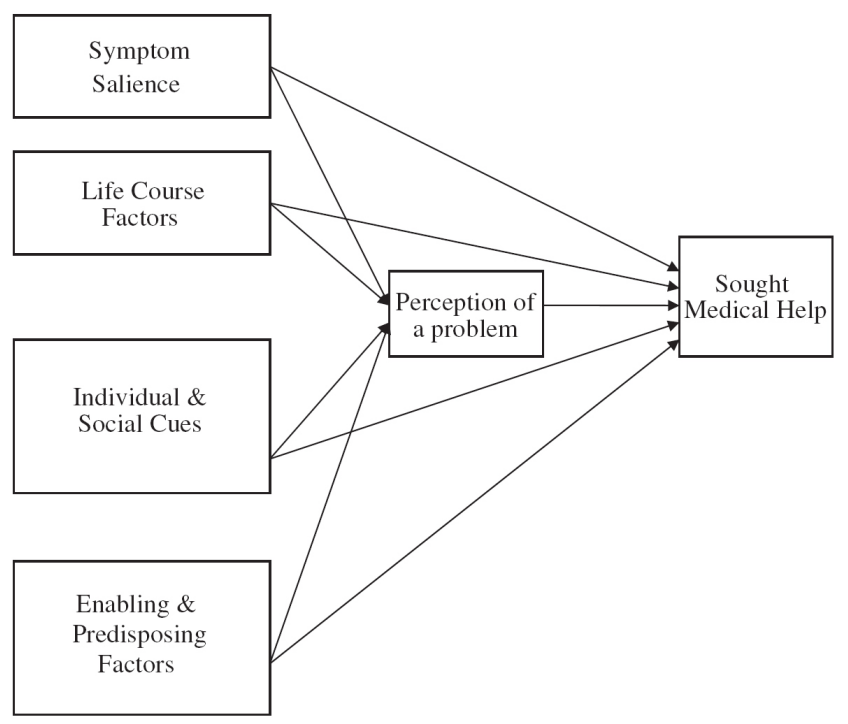

Figure 1. Conceptual diagram of hypothesized model of helpseeking for infertility. 
life course cues include age, parity, and, because marriage is often a trigger for normative childbearing, marriage.

Individual cues for perceiving and seeking help for fertility problems include the importance of motherhood as a life goal and religiosity. We hypothesize that women who have more conventional values, as indexed by religiosity and motherhood values, are more likely to pay attention to signals of infertility. Helpseeking theories suggest that social cues should be an important determinant of perceiving a problem and seeking treatment. In the case of infertility, the most important of these social cues is likely to be partner's desires, and we examine the effect of partner's perceived fertility desires on self perception and help seeking.

The high cost of infertility treatment in the US makes income a key enabling factor. In this study, we examine current family income. Although it is unfortunate that we have no measure of health insurance coverage at the time of the episode, only recently have infertility treatments been covered by US health insurance programs. Following research showing that social network support predicts helpseeking (Carpentier \& White, 2002), we also include expressive social support as a general enabling factor. To assess factors that generally predispose one to treatment seeking, we have measures of education, general health, internal health locus of control, and ethical concerns about artificial reproductive technologies (ART). We control for race/ethnicity because of the greater likelihood of medical mistrust among minority women (Thompson, Valdismarsdottir, Winkel, Jandorf, \& Redd, 2004).

As far as we are aware, this is the first application of a general helpseeking model to infertility and one of the broadest tests of the helpseeking framework. Because this data set includes only women, we cannot test whether the model works similarly for men and women. Although the lifetime definition of infertility allows us to include a larger pool of women and a longer time frame for helpseeking, this strategy creates some temporal disorder, where we use current circumstances (attitudes, income, and intentions) to predict lifetime experiences with helpseeking. We believe the net result of using current circumstances to predict cumulative behavior is to underestimate the strength of relationships observed. For example, we would expect helpseeking to be related more strongly to income at the time of the episode than to current income and to fertility intentions at the time than fertility intentions in 2002. Thus, we believe this design is a conservative test that is more likely to err on the side of underestimating the strength of relationships than to find weak relationships statistically significant.

\section{Study design}

\section{Sample}

The data reported here come from telephone interviews with a random sample of 580 Midwestern US women ages 25-50 called in the spring of 2002. Households were identified through random digit dialing and screened for the presence of women ages 25-50. We over-sampled in Census Tracts in which $40 \%$ or more claimed minority status. Overall, the response rate was $60 \%$ ( $80 \%$ contact rate and $75 \%$ cooperation among those contacted). The sample is $15 \%$ African American compared to $11 \%$ in the region. Interviews were conducted in English, but the sample only slightly under-represents Latinas (3.8\% compared to $4.5 \%$ in the 12 -state area). The age distribution is virtually identical to that of women ages 25-50 in the 12-state region. As is usual in survey research, our sample over-represents well-educated women, with $36 \%$ reporting a college degree compared to $27 \%$ in the Census.

In this paper, we analyze a subsample of 196 women identified as ever experiencing infertility. This subsample includes women who answered yes to one of two questions: (1) "Have you ever had a time in your life when you tried to get pregnant for more than 12 months, but did not conceive?" (2) "Have you ever had a time in your life of 12 months or more during which you were having regular intercourse without contraception and you didn't get pregnant?" or (3) gave an answer of 12 months or more to the question, "How many months did you have to try before you got pregnant?" The latter question was embedded in a series of questions about each pregnancy and was asked whenever the respondent reported that she had been trying to get pregnant at the time of her nth conception. Overall, fully one-third of the sample met a medical definition of infertility, a figure very comparable to two British studies that report lifetime levels of infertility of 30-35\% (Greenhill \& Vessey, 1990; page. 1989). These 196 women are the subsample used in the analysis. 


\section{Measurement}

\section{Dependent variables}

Medical helpseeking is a dummy variable coded 1 if the woman reported consulting a doctor about infertility or that any of her pregnancies were the result of medical treatment. Approximately one-third of the women who saw a doctor because of fertility concerns never took this beyond an office visit, but 57 of the 85 women who saw a doctor went forward with tests or treatments to deal with their infertility. Perception of fertility problems is measured in this study by a single yes/no item: "Do you think of yourself as someone who has - or has had-fertility problems?"

\section{Symptom salience}

We use two measures to tap symptom salience. Trying is a dummy variable that identifies the 123 women whose failure to conceive during 12 months of unprotected intercourse occurred while they were trying to get pregnant or who reported that their nth pregnancy was planned and it took more than 12 months of unprotected intercourse to achieve. Another 73 women are coded zero on this variable. The latter group reported that they had 12 months or more of unprotected intercourse without getting pregnant but said they were not trying to get pregnant at the time. Intensity of childbearing plans is measured by a variable assessing how sure women are that they intend (more) children. The 4-point scale combines information from two questions: "Do you intend to have a(nother) baby?" How sure are you that you will/will not have children? Intend more is scored with $4=$ intend, very sure; $3=$ intend, pretty sure; 2 = intend, not very sure; and 1 = do not intend.

\section{Life course cues}

Age is included in the multivariate models as a dummy variable scored 1 if over 30 and 0 if 30 or younger. Preliminary analysis suggested non-linear effects, with age 30 being a threshold for perceiving a problem or seeking medical help. The survey included data about marital and cohabitation status and marital order, but preliminary analyses suggested that the critical distinction was ever married versus never married. Although more detail is provided in the tabular analysis, the multivariate analysis uses a dummy variable for ever married with never married women as the omitted category. Parity refers to the number of children a woman has borne.
Individual and social cues

Value of motherhood is a unidimensional, 5-item scale $(\alpha=.70)$ that taps importance of motherhood as a life identity. The scale averages four items provided in a $4=$ strongly agree to $1=$ strongly disagree format (Women who do not want children are unnatural; I feel I would be incomplete as a woman if I could not have a child; I can see a number of advantages to not having children [reverse coded]; I can visualize a happy life without children [reverse coded]) and an item asking respondents to rate "the importance of raising children and having a family" as a life goal from 4 = very important to $1=$ not important. Religiosity is a 3-item scale ( $\alpha=.80)$, scored $1=$ low and $5=$ high. Items include how much religious beliefs influence daily life, frequency of prayer, and how close respondent feels to God.

Partner wants (more) children is a measure of social cues for treatment seeking. Respondents in union were asked whether their husband/partner would like to have a(nother) baby. Those who said "definitely yes" are coded 1 and all others, including those not in union, are coded 0.

Predisposing and enabling conditions.

Total family income was recorded in 12 categories, ranging from under $\$ 5000$ to over $\$ 100,000$. Each category has been recoded to its mean (with the top category coded as $\$ 110,000$ ) and expressed in $\$ 10,000$ units to make the coefficients readily interpretable. For the descriptive analysis in Table 1 only, it is presented in categories of income-to-need (family income relative to the poverty level) to make it comparable to similar tabulations from the US National Survey of Family Growth (NSFG). Expressive social support is measured by an averaged 8-item scale designed to tap medically relevant social support (Sherbourne \& Stewart, 1991). Respondents were asked how often various forms of social support (e.g., someone to give you good advice about a crisis; someone to share your most private worries and fears with) were available when they needed it. Answers ranged from $4=$ often to $1=$ never. The single factor scale has an a of .93. Internal health locus of control is designed to measure the extent to which individuals believe that they-rather than their doctors - are responsible for their health (Wallston, Wallson, \& DeVellis, 1978). It is measured as the mean of 5 items provided in a strongly agree (3) to strongly disagree (0) format: If 
Table 1. Variables used in the analysis

Name: Description

Proportion/Mean

S.D.

Seek help: "During any of your relationships, have you or your partner ever been to a doctor or clinic to talk about ways to help you get pregnant?" or "Did you receive medical treatment to help you get pregnant?" asked for each pregnancy where respondent reported that she had been trying to get pregnant at time of conception. 1 = yes, $0=$ no

Perceive problem: "Do you think of yourself as someone who has or has had fertility problems?" $1=$ yes, $0=$ no

Trying: "Have you ever had a time in your life when you tried to get pregnant for more than 12 months but did not conceive?" 1 = yes, $0=$ no

Intend more children: "Do you intend to have a(nother) baby?" $4=$ yes, very sure; 3 = yes, pretty sure; 2 = yes, not very sure; $1=$ no

Age over 30: Current age coded $1=31-50,0=25-30$

.86

Ever married: 1 = married, divorced, separated, widowed, $0=$ never married

Value of motherhood: 5-item scale. Examples, "I would feel incomplete as a woman if I could not have children," "Women who don't want children are unnatural." $4=$ strongly agree to $1=$ strongly disagree. $\alpha=.70$

Religiosity: 3-item scale. Example, "In general how much would you say your religious beliefs influence your daily life?" 5 = high to $1=$ low. $a=.80$

Partner wants more children: Would your husband/partner like to have a/nother baby? $1=$ definitely yes, $0=$ other, including no partner

Family income: Total family income expressed in $\$ 10,000$, range \$.5-\$11

Social support: 8-item scale. "How often is each of the following kinds of support available to you if you need it?" Example, "Someone to give you good advice about a crisis?" $4=$ often to $1=$ never. $a=.93 \quad 3.64$

Internal health locus control: 5-item scale. Example, "When I get sick, I am to blame," 3 = strongly agree to $0=$ strongly disagree. $\alpha=.66$

Subjective health: "In general, would you say your own health is excellent, good, fair, or poor?" $4=$ excellent to 1 = poor.

Ethical concerns: ART 5-item scale. Mean of five situations ranging from insemination with partner's sperm to surrogate mothers rated 2 = serious ethical problem, $1=$ some ethical problem, or $0=$ not an ethical problem. $\alpha=.86$

Education: Years of formal schooling, range $=9-22$.

I get sick, it is my own behavior which determines how soon I get well again; I am in control of my own health; When I get sick, I am to blame; If I take care of myself, I can avoid illness; if I take the right actions, I can stay healthy. a is .66. Subjective health is a standard single-item measure of subjective health, "In general, would you say your own health is excellent, good, fair, or poor?" coded $4=$ excellent and $1=$ poor. Ethical concerns about ART are measured by a 5-item scale. Respondents were asked whether five procedures (ranging from artificial insemination with husband's sperm to surrogate mothers) posed no ethical problems (0), some ethical problems (1), or serious ethical problems (2). The scale $(\alpha=.86)$ is the mean of the 5 items. Education is coded continuously in years completed. A dummy variable identifies women who were Minority (Hispanic or non-White).

Table 1 lists the variables used in the analysis and their definitions. Means and standard deviations are presented for the ordinal and continuous variables, and proportions coded 1 are given for the dummycoded variables.

\section{Missing values}

The level of missing data was small in this data set. The largest problem was 40 individuals (18 in the subsample of infertile women) who did not answer the family income questions. We used the Expecta- 
tion Maximization module in SPSS (Hill, 1987) to impute values for cases with missing values on income or any of the other variables. Preliminary analyses included an indicator of imputed values, but this variable was not significant in itself nor did the effect of income depend on whether results were imputed.

\section{Analysis}

We posited a two-step model of helpseeking in which variables affect helpseeking directly and also indirectly through the process of cognitive appraisal. Because both dependent variables-perception of a problem and helpseeking-are dichotomous, logistic regression is the most appropriate method of analysis.

\section{Findings}

\section{Descriptive data}

Of the 196 women identified as infertile, approximately one-third $(35 \%)$ reported perceiving that they have or have had a fertility problem and $40 \%$ reported seeking medical treatment. Although it appears that more women sought help than perceived a problem, the difference in the two figures is not statistically significant.

To illustrate the distribution of these outcomes, Table 2 shows the bivariate relationships of the two dependent variables with standard demographic background variables. At the bivariate level, the likelihood that a woman will report perceiving a fertility problem is significantly related only to parity. Women who are childless are significantly more likely to perceive a fertility problem. When we turn to treatment seeking, marital status, education, and family income are significant bivariate correlates. Almost no nevermarried infertile women reported seeking medical help. Both education and income are positively associated with treatment seeking. Women with college degrees are twice as likely to seek help as those with 12 years of schooling or less, and infertile women with the highest family incomes are three times more likely to have sought medical treatment than women with the lowest family incomes.

The last row in Table 2 demonstrates that the likelihood of seeking help is dramatically higher among those who perceive a fertility problem but that it is not confined to them. Although $77 \%$ of those who
Table 2. Percent who perceive fertility problems or seek medical treatment among sample of 196 women reporting an infertility episode

\begin{tabular}{|c|c|c|c|}
\hline Sample characteristics & $N$ & $\begin{array}{l}\% \text { Perceive } \\
\text { a problem }\end{array}$ & $\begin{array}{c}\% \text { Seek } \\
\text { treatment }\end{array}$ \\
\hline Total & 196 & 35 & 40 \\
\hline \multicolumn{4}{|l|}{ Age } \\
\hline Under 30 & 22 & 18 & 18 \\
\hline $30-39$ & 80 & 41 & 41 \\
\hline 40 and over & 94 & 34 & 44 \\
\hline \multicolumn{4}{|l|}{ Parity } \\
\hline Zero & 28 & $61^{\mathrm{a}}$ & 50 \\
\hline One or more & 168 & $31^{\mathrm{b}}$ & 38 \\
\hline \multicolumn{4}{|l|}{ Marital and union status } \\
\hline Never married & 17 & 18 & $6^{\mathrm{a}}$ \\
\hline Formerly married & 36 & 22 & 31 \\
\hline Currently married & 143 & 41 & $46^{b}$ \\
\hline \multicolumn{4}{|l|}{ Education } \\
\hline 12 years or less & 61 & 26 & $26^{a}$ \\
\hline Some college & 81 & 38 & 42 \\
\hline College degree & 53 & 42 & $53^{b}$ \\
\hline \multicolumn{4}{|l|}{ Income-to-need ratio } \\
\hline$<300 \%$ of poverty line & 59 & 24 & $22^{a}$ \\
\hline $300-599 \%$ of poverty line & 86 & 37 & 41 \\
\hline$>599 \%$ of poverty line & 51 & 45 & $59^{b}$ \\
\hline \multicolumn{4}{|l|}{ Race/ethnicityc } \\
\hline Latina & 11 & 27 & 36 \\
\hline African American & 30 & 27 & 20 \\
\hline NonHispanic White & 147 & 37 & 44 \\
\hline \multicolumn{4}{|l|}{ Perceive fertility problem } \\
\hline No & 69 & & $20^{\mathrm{a}}$ \\
\hline Yes & 127 & & $77^{b}$ \\
\hline
\end{tabular}

a,b Tukey's test of honestly significant differences between pairs of categories indicated by a,b significant at ${ }^{*} p<.05$, two tailed tests. All other comparisons are not significant.

${ }^{\mathrm{c}}$ Women who did not fall in these 3 race/ethnic categories $(n=15)$ are excluded from this panel.

perceived a problem reported seeking help, so did $20 \%$ of those who did not perceive a problem. The possible reasons for seeking help among this latter group will be discussed later.

\section{Multivariate analysis: Testing a mediation model of helpseeking}

Table 3 summarizes the results of our logistic regression analysis. Model I shows the relationship between helpseeking predictors and perception of a fertility problem. Controlling for all other variables in 
Table 3. Predictors of perception of a fertility problem and of medical helpseeking in a sample of infertile women.

\begin{tabular}{|c|c|c|c|}
\hline Independent variables & $\begin{array}{c}\text { I } \\
\text { Perception } \\
\text { of } \\
\text { problems } \\
B \\
\text { (SE) }\end{array}$ & $\begin{array}{c}\text { II } \\
\text { Sought } \\
\text { medical } \\
\text { help } \\
B \\
\text { (SE) }\end{array}$ & $\begin{array}{l}\text { III } \\
\text { Sought } \\
\text { medical } \\
\text { help } \\
\text { B } \\
\text { (SE) }\end{array}$ \\
\hline Trying & $\begin{array}{l}2.083^{* *} \\
(.506)\end{array}$ & $\begin{array}{l}1.812^{* *} \\
(.429)\end{array}$ & $\begin{array}{l}1.200^{*} \\
(.475)\end{array}$ \\
\hline Intend (more) children & $\begin{array}{l}.395 \\
(.213)\end{array}$ & $\begin{array}{l}.033 \\
(.201)\end{array}$ & $\begin{array}{l}-.172 \\
(.228)\end{array}$ \\
\hline Ever married & $\begin{array}{l}.459 \\
(.896)\end{array}$ & $\begin{array}{l}1.519 \\
(1.147)\end{array}$ & $\begin{array}{l}1.416 \\
(1.233)\end{array}$ \\
\hline Parity & $\begin{array}{l}-.625^{* *} \\
(.192)\end{array}$ & $\begin{array}{l}-.161 \\
(.146)\end{array}$ & $\begin{array}{l}.060 \\
(.168)\end{array}$ \\
\hline Age over 30 & $\begin{array}{l}1.233^{*} \\
(.713)\end{array}$ & $\begin{array}{l}1.021 \\
(.694)\end{array}$ & $\begin{array}{l}.706 \\
(.770)\end{array}$ \\
\hline Value of motherhood & $\begin{array}{l}.471 \\
(.470)\end{array}$ & $\begin{array}{l}.725 \\
(.443)\end{array}$ & $\begin{array}{l}.680 \\
(.505)\end{array}$ \\
\hline Religiosity & $\begin{array}{l}.154 \\
(.251)\end{array}$ & $\begin{array}{l}-.098 \\
(.227)\end{array}$ & $\begin{array}{l}-.188 \\
(.246)\end{array}$ \\
\hline Husband wants (more) children & $\begin{array}{l}1.104 \\
(.608)\end{array}$ & $\begin{array}{l}1.095 \\
(.593)\end{array}$ & $\begin{array}{l}.934 \\
(.666)\end{array}$ \\
\hline Family income in $\$ 10,000$ s & $\begin{array}{l}.132 \\
(.083)\end{array}$ & $\begin{array}{l}.172^{*} \\
(.081)\end{array}$ & $\begin{array}{l}.155 \\
(.089)\end{array}$ \\
\hline Social Support & $\begin{array}{l}.338 \\
(.412)\end{array}$ & $\begin{array}{l}-.022 \\
(.388)\end{array}$ & $\begin{array}{l}-.117 \\
(.435)\end{array}$ \\
\hline Health locus of control & $\begin{array}{l}-.665 \\
(.492)\end{array}$ & $\begin{array}{l}-1.135^{*} \\
(.493)\end{array}$ & $\begin{array}{l}-1.130^{*} \\
(.554)\end{array}$ \\
\hline Subjective health & $\begin{array}{l}-.729^{* *} \\
(.274)\end{array}$ & $\begin{array}{l}-.061 \\
(.255)\end{array}$ & $\begin{array}{l}.300 \\
(.302)\end{array}$ \\
\hline Ethical concerns about ART & $\begin{array}{l}-.251 \\
(.417)\end{array}$ & $\begin{array}{l}-.122 \\
(.394)\end{array}$ & $\begin{array}{l}.049 \\
(.428)\end{array}$ \\
\hline Years of education & $\begin{array}{r}-.058 \\
(.098)\end{array}$ & $\begin{array}{l}.063 \\
(.089)\end{array}$ & $\begin{array}{l}.090 \\
(.093)\end{array}$ \\
\hline Minority race/ethnicity & $\begin{array}{l}-.374 \\
(.531)\end{array}$ & $\begin{array}{l}-.559 \\
(.502)\end{array}$ & $\begin{array}{l}-.575 \\
(.566)\end{array}$ \\
\hline Perception of problems & & & $\begin{array}{l}2.414^{* *} \\
(.492)\end{array}$ \\
\hline Constant & -3.071 & -4.973 & -5.664 \\
\hline Nagelkerke $R^{2}$ & .473 & .421 & $.549^{\mathrm{a}}$ \\
\hline
\end{tabular}

Logistic regression coefficients reported (s.e. in parentheses), $n=196$. ${ }^{*} p<.05^{* *} p<.01$ two-tailed tests.

${ }^{\text {a }}$ Change in explained variance significant at $p<.01$.

the model, women who experienced infertility while trying to conceive were 8 times more likely to perceive a fertility problem than women who were not trying to conceive $\left(\mathrm{e}^{2.083}=8.02\right)$. With each additional child, the likelihood that a woman would perceive herself as having a fertility problem decreased by about half $\left(\mathrm{e}^{-.625}=.54\right)$. Finally, subjective health had a significant relationship with perception of infertility. As prior results on co-morbidity would suggest, results show a strong negative association between perceived good health and likelihood of being aware of a fertility problem. Education and income were not significantly related to perception of infertility, even if entered separately. Although coefficients for age, intending more children, and husband wanting more children were in the expected direction, none were significant in this small sample. Overall, the evidence in this analysis suggests that infertile women who have fewer children, worse subjective health, and were actively trying to get pregnant were those most likely to perceive themselves as having a fertility problem. Measures of socioeconomic status were not related significantly to self awareness. With the possible exception of the strong role of the subjective health variable, these results focus our attention on various dimensions of symptom salience as important for understanding perception of fertility problems.

The next step in the analysis is to determine whether these variables are related to helpseeking, either directly or indirectly through perception of a problem. Model II of Table 3 demonstrates that three of the independent variables are significantly associated with medical helpseeking. Women who experienced infertility while trying to get pregnant are significantly and substantially more likely to have sought help $\left(\mathrm{e}^{1.812}=6.12\right)$. As expected, family income was significantly positively associated with seeking help, with each increment of $\$ 10,000$ in family income associated with a 19\% higher likelihood of seeking help $\left(\mathrm{e}^{\cdot 172}=1.19\right)$. A higher internal health locus of control was associated with lower likelihood of seeking treatment. This scale is designed to measure sense of individual responsibility for health, and so women who felt that they, rather than their doctors, controlled their health were less likely to seek medical treatment for infertility. Contrary to expectations, education, subjective health, social support, ethical concerns about ART, and minority status were not directly related to medical helpseeking.

The issue addressed in Model III is whether perception of a problem mediates the associations between the variables in Model II and help seeking. As suggested by the significant bivariate results in Table 2 , perception of a problem was a powerful correlate of treatment seeking, and the change in the model fit was significant and large between Models II and III (model $\left.\chi^{2}=29.119, \mathrm{df}=1, p=.0001\right)$. Evidence for 
mediating effects was weaker. Support for a mediation hypothesis requires that (a) the proposed predictors of helpseeking are significantly related to perception of a problem and to helpseeking; (b) perception of a problem is significantly related to helpseeking; and (c) that the relationships between proposed predictors and helpseeking are significantly reduced when perception of a problem is included in the analysis (Baron \& Kenny, 1986). Only in the case of trying did the data meet all of these criteria: all of the appropriate relationships were significant and the reduction in the coefficient for trying when perception of a problem is controlled was significant (post-hoc mediation test, $z=3.154, p<.01$ ) (Holmbeck, 2002). Despite significant mediation, however, symptom salience retained a significant, direct relationship with helpseeking. Although poor health and low parity were associated with higher odds that women recognize the signs of infertility and this, in turn, was associated with higher odds of seeking help, mediation was ruled out because health and parity had no direct effects on medical helpseeking. ${ }^{1}$

Finally, we explored whether the effects of helpseeking predictors depended on the cognitive dimension of perception. To test this hypothesis, we created 14 multiplicative terms (e.g., ever married $\times$ perceived problem) and added these as a set to the equation in Model III, which already included the main effects of all variables. As a set, the interaction terms were not significant $\left(\chi^{2}=18.220, \mathrm{df}=14, p=.19\right)$, and none of the individual coefficients were significant using the Bonferroni corrected $p$-value (Olejnik, Li, Supattathum, \& Huberty, 1997). This suggests that the two interactions that were significant at the conventional $p<.05$ when entered one at a time may be the results of *inflation due to running 14 tests. The negative relationship of ethical concerns about ART and of internal health locus of control were both stronger for those who perceived a problem than for those who did not $(b=-2.90, p<.05$ and $b=-3.03, p<.01$, respectively). Although these results may be the result of

\footnotetext{
${ }^{1}$ Coefficients for parity $(z=2.20, p<.01)$ and subjective health $(z=2.338, p<.01)$ do change significantly when perception of problems is added in Model III. This is often interpreted as evidence of suppression, however an additional test suggested by Maassen and Bakker (2001) does not support this conclusion: when parity and subjective health are added to a model already including perception of a problem, the increase in model $\chi^{s}$ is not significant $\left(\chi^{2}=1.087, \mathrm{df}=2, p=.581\right)$.
}

inflated likelihood of rejecting a null hypothesis, they suggest that factors that deter helpseeking work primarily on women who have made the cognitive leap to perceiving that they have a fertility problem. This possibility merits greater research attention.

\section{Discussion and conclusion}

This analysis uses data from a random sample of 196 US Midwestern women to examine a helpseeking model for infertility. Our data, using a lifetime prevalence measure of infertility, show that approximately one-third of women identified as infertile perceive that they have or have had a fertility problem and a comparable minority ( $40 \%$ ) have sought treatment.

As theory suggests, the cognitive dimension of appraisal, perception of a fertility problem, plays a central and complex role in treatment seeking. Perception of a problem has a strong direct effect on helpseeking, and it significantly but only partially mediates the effect of symptom salience. Two variables with strong associations with perceiving a problem, parity and subjective health, had only indirect effects on helpseeking: Poor health and low parity were associated with higher odds that women will recognize the signs of infertility and, in turn, seek help, but they had no direct effects on medical helpseeking. Internal health locus of control had direct effects on helpseeking independent of perception of a problem. As currently measured, family income had only a modest relationship to helpseeking and this relationship was insignificant after perception of a problem was controlled.

Overall, this study of medical helpseeking for infertility supports helpseeking theory and the central role of cognitive appraisal in such a model. Although we had more single-item indicators that we would like and there are issues of temporal order, our results provide strong support for the central role of cognitive appraisal. They also support the importance of symptom salience, co-morbidity, attitudes toward medical treatment (in this case, internal health locus of control).

In addition to providing a broad test of helpseeking theory, two findings from this study are noteworthy for infertility in particular. First, only about one-third of women who met the medical criterion for infertility acknowledged that they have or had a fertility problem. Because previous studies have not had the necessary sample of non-helpseekers to 
make such an estimate, this unique finding raises new questions about why so few women recognize that they meet the criteria of infertility. The most likely possibilities include that they may be: not trying to conceive despite having unprotected intercourse, rejecting a stigmatized identity (Greil, 1991); attributing the problem to their husbands rather than themselves; disagreeing that the problem for which they were treated qualifies as a fertility problem; thinking that a wait of 1,2 , or even 3 years is normal; presuming that successful childbearing means they were not infertile; or considering failure to conceive a blessing rather than a problem. Because our data suggest that perceiving an infertility problem is central to the medical helpseeking process, it is important to develop a better understanding of when and why women recognize that their failure to conceive within 12 months is a signal of problems. Second, our finding that good overall health may act as a barrier to perceiving fertility problems is a critical finding because it is precisely this group who is most likely to benefit from treatment.

The major strength of this study is the inclusion of a random sample of infertile women, including those who do not as well as those who do seek help. This sample allows a broader test of helpseeking processes than is possible in clinical samples. Although this study confirms the importance of some variables suggested by helpseeking theories, we found no significant effects for over half of our variables. Some of these null findings (for example, for own and husband/partner's intentions) might be attributed to temporal measurement error, while other predictors are insignificant largely because of the low power of our sample. Overall, we believe the model provides a useful approach to examining helpseeking for infertility and confirms the theoretically important role of cognitive appraisal as well as of structural conditions such as income. Further research to identify the pathways that lead women toward or away from treatment would benefit from a panel study that follows a larger group of women over a 3-5 year period and information about the social processes - in particular, interactions with husbands or partners - that affect perception of a problem.

\section{Acknowledgments}

We wish to thank Laurie Scheuble, Mary Casey Jacob, and Naomi Lacy, who are part of the team that designed the larger study of which this is a part. The University of Nebraska provided essential funding. An earlier version of this paper was presented at the 2003 annual meetings of the Population Association of America. We also thank reviewers for thoughtful comments on an earlier version of this manuscript.

\section{References}

Anderson (1968): R. Anderson, A behavioral theory of families' use of health services, University of Chicago, Center for Health Administration Studies, Chicago (1968).

Callan, Kloske, Kashima, \& Hennessey (1988): V.J. Callan, B. Kloske, Y. Kashima and J.F. Hennessey, Toward understanding women's decisions to continue or stop in vitro fertilization: The role of social, psychological and background factors, Journal of In vitro Fertilization and Embryo Transfer 5 (1988), pp. 363-369.

Carpentier \& White (2002): N. Carpentier and D. White, Cohesion of the primary social network and sustained service use before the first psychiatric hospitalization, Journal of Behavioral Health Services \& Research 29 (2002), pp. 404-419.

Chandra \& Stephen (1998): A. Chandra and E.H. Stephen, Impaired fecundity in the United States: 1982-1995, Family Planning Perspectives 30 (1998), pp. 34-42.

De Nooijer, Lechner, \& de Vries (2003): J. De Nooijer, L. Lechner and H. de Vries, Social psychological correlates of paying attention to cancer symptoms and seeking medical help, Social Science \& Medicine 56 (2003), pp. 915-921.

Fortier, Wright, \& Sabourin (1992): C. Fortier, J. Wright and S. Sabourin, Soutien social et abandon de la consultation médicale en clinique de fertilité, Journal International de Psychologie 27 (1992), pp. 33-48.

Greenhill \& Vessey (1990): E. Greenhill and M. Vessey, The prevalence of subfertility: A review of the current confusion and a report of two new studies, Fertility and Sterility 54 (1990), pp. 978-983.

Greil (1991): A.L. Greil, A secret stigma: The analogy between infertility and chronic illness and disability, Advances in Medical Sociology 2 (1991), pp. 17-38.

Hannestad, Rortveit, \& Hunskaar (2002): Y.S. Hannestad, G. Rortveit and S. Hunskaar, Help-seeking and associated factors in female urinary incontinence. The Norwegian EPINCONT study, Scandinavian Journal of Primary Health Care 20 (2002), pp. 102-108. 
Hill (1987): M. Hill, SPSS missing value analysis 7.5, SPSS Inc, Chicago, IL (1987).

Holmbeck (2002): G.N. Holmbeck, Post-hoc probing of significant moderational and mediational effects in studies of pediatric populations, Journal of Pediatric Psychology 27 (2002), pp. 87-96.

Hunter, Grunfeld, \& Ramirez (2003): M.S. Hunter, E.A. Grunfeld and A.J. Ramirez, Hep-seeking intentions for breastcancer symptoms: A comparison of the self-regulation model and the theory of planned behavior, British Journal of Health Psychology 8 (2003), pp. 319-334.

Lefebvre, Lesage, Cyr, Toupin, \& Fournier (1998): J. Lefebvre, A. Lesage, M. Cyr, J. Toupin and L. Fournier, Factors related to utilization of services for mental health reasons in Montreal, Canada, Social Psychiatry and Psychiatric Epidemiology 33 (1998), pp. 291-299.

Maassen \& Bakker (2001): G.H. Maassen and A.B. Bakker, Suppressor variables in path models, Sociological Methods $\mathcal{E}$ Research 30 (2001), pp. 241-270.

Malcolm \& Cumming (2004): C.E. Malcolm and D.C. Cumming, Follow-up of infertile couples who dropped out of a specialist fertility clinic, Fertility and Sterility 81 (2004), pp. 269-270.

Malin, Hemminki, Raikkonen, Sihvo, \& Perala (2001): M. Malin, E. Hemminki, O. Raikkonen, S. Sihvo and M-L. Perala, What do women want? Women's experiences of infertility treatment, Social Science $\mathcal{E}$ Medicine 53 (2001), pp. 123-133.

Mechanic (1968): D. Mechanic, Medical sociology: A selective view, Free Press, New York (1968).

Olejnik, Li, Supattathum, \& Huberty (1997): S. Olejnik, J. Li, S. Supattathum and C.J. Huberty, Multiple testing and statistical power with modified Bonferroni procedures, Journal of Educational and Behavioral Statistics 22 (1997), pp. 389-406.

Page (1989): H. Page, Estimation of the prevalence and incidence of infertility in a population: A pilot study, Fertility and Sterility 51 (1989), pp. 571-577.

Pescosolido (1992): B.A. Pescosolido, Beyond rational choice: The social dynamics of how people seek help, American Journal of Sociology 97 (1992), pp. 1096-1138.

Robinson \& Swindle (2000): R.L. Robinson and R.W. Swindle, Premenstrual symptom severity: Impact on social functioning and treatment-seeking behaviors, Journal of Women's Health E Gender-based Medicine 9 (2000), pp. 757-764.
Salander, Bergenheim, Hamberg, \& Henrikkson (1999): P. Salander, A.T. Bergenheim, K. Hamberg and R. Henrikkson, Pathways from symptoms to medical care: A descriptive study of symptom development and obstacles to early diagnosis in brain tumour patients, Family Practice 16 (1999), pp. 143-148.

Schmidt \& Münster (1995): L. Schmidt and K. Münster, Infertility, involuntary infecundity, and the seeking of medical advice in industrialized countries 1970-1992: A review of concepts, measurements, and results, Human Reproduction 10 (1995), pp. 1407-1418.

Sciarra (1994): J. Sciarra, Infertility: An international health problem, International Journal of Gynecology E Obstetrics 46 (1994), pp. 155-163.

Shaw (1999): C. Shaw, A framework for the study of coping, illness behavior and outcomes, Journal of Advanced Nursing 29 (1999), pp. 1246-1255.

Shaw (2001): C. Shaw, A review of the psychosocial predictors of help-seeking behaviour and impact on quality of life in people with urinary incontinence, Journal of Clinical Nursing 10 (2001), pp. 15-24.

Sherbourne \& Stewart (1991): C.D. Sherbourne and A.L. Stewart, The MOS social support survey, Social Science and Medicine 32 (1991), pp. 705-714.

Thompson, Valdismarsdottir, Winkel, Jandorf, \& Redd (2004): H. Thompson, H.B. Valdismarsdottir, G. Winkel, L. Jandorf and W. Redd, The group-based medical mistrust scale: Psychometric properties and association with breast cancer screening, Preventive Medicine 38 (2004), pp. 209-218.

van Balen \& Verdurmen (1999): F. van Balen and J. Verdurmen, Medical anxiety and the choice for treatment: The development of an instrument to measure fear of treatment, Psychology of Health 14 (1999), pp. 927-935.

van Balen, Verdurmen, \& Ketting (1997): F. van Balen, J. Verdurmen and E. Ketting, Choice and motivations of infertile couples, Patient Education and Counseling 31 (1997), pp. 19-27.

Wallston, Wallson, \& DeVellis (1978): K.A. Wallston, B.S. Wallson and R. DeVellis, Development of the multidimensional health locus of control (MHLC) scales, Health Education Monographs 6 (1978), pp. 160-170.

Zola (1973): I.K. Zola, Pathways from the doctor: From person to patient, Social Science \& Medicine 7 (1973), pp. 677-689. 